\title{
Validity and Reliability of the School's Emotional Climate Scale
}

\author{
Efraim Öztürk ${ }^{1 *}$, Mukadder Boydak Özan ${ }^{2}$ \\ Educational Management Discipline, Firat University, Turkey
}

Corresponding Author: Efraim Öztürk, ozturkefraim@gmail.com

This article is produced from Efraim Ozturk's doctoral thesis.

\section{ARTICLE INFO}

Article history

Received: September 03, 2019

Accepted: November 23, 2019

Published: December 31, 2019

Volume: 10 Issue: 6

Advance access: December, 2019

Conflicts of interest: None

Funding: None

\begin{abstract}
The aim of this study is to develop and validate the School's Emotional Climate scale. To this end, 683 teachers working in elementary and middle schools were recruited. An item pool with 39 items was created based on an extensive literature review and expert opinions. The items were reviewed by experts and seven items were dropped out from the item pool. EFA was conducted with 32 items. Based on the results of EFA, thirteen items were removed, which left 19 items with three factors. In order to test this structure, CFA was conducted. According to the CFA results, the scale was found to be reliable, which is also proved through Cronbach alpha reliability coefficient values. The final form of the scale consisted of 19 items with three factors entitles as emotional association, empathy, and emotional fatigue. The limitations and suggestions for future research is discussed.
\end{abstract}

\section{Key words:}

Emotional Climate,

Schools,

Teachers

\section{INTRODUCTION}

There exist many emotions for human beings to experience in and out of work and they are indispensable of life and determinant of behaviors (Erkuş \& Günlü, 2008). Work life, which encourage people to socialize, also brings love, anger, fear, happiness and so on (Seçer, 2005). Emotions need be managed carefully since they can have a positive or negative effects on life (Akın, 2004; Kervanc1, 2008). More specifically, emotions are social structures that may destroy or improve the institution (Fineman, 1993). Since employees' emotions are the factors that affect the emotional climate of an organization, those emotions need to be managed carefully (Kervanc1, 2008).

Emotional climate is the common emotional arousal situation created by a community (Tobin, Ritchie, Oakley, Mergrad \& Hudson, 2013). Emotional climate, the common feelings that emerge as a result of the interaction among employees (De Rivera \& Paez, 2007), is affected by many events that affect employees (Ruiz, 2007). Depending on whether the effect is positive or negative, the emotional climate is called a positive or negative emotional climate. While there is a common happiness and joy in a positive emotional climate, there is a common sadness, fear or anger in a negative emotional climate (Tobin et al., 2013; Turner, 2007). Negative emotions, if felt often in organizations, cause organizations to wear out. Therefore, it is critical for organizations to provide emotional climate-related training programs for individuals or groups working in the organization (Kırel, 2007).

Work life cannot be isolated from emotions (Akçay \& Çoruk, 2012). Especially in institutions whose input, output, and control mechanism that directs this process are human, it is even more important that emotions are experienced in a controlled way. The emphasis on information in education should be given to emotions as well (Zembylas, 2005) since emotions affect the climate of classrooms (Schutz, Aultman and Williams-Johnson, 2009) and positive climate increases learners' motivation, academic performance, and learning competence (Bellocchi, Ritchie, Tobin, Sandhu, \& Sandhu, 2013). Briefly, positive school climate ensures the development of youth and encourage them to produce and contribute (Thapa, Cohen, Guffrey \& Higgins-D’Alessandro, 2013). In addition, positive development of school environment increases the positive emotional interactions among school stakeholders. Hargreaves (2000) put strong emphasis on the emotional bond between the teacher and the student and stated that the stronger this bond, the better the quality of education will increase.

A positive emotional climate in organizations motivates employees and is effective in increasing their performance and commitment to their organizations (Akçay \& Çoruk, 2012). In addition, managers' efforts to create a positive emotional climate also improve employees' commitment to their duties by developing an effort in this direction (Kahn, 
1993) and highlight the vision of employees (Edmondson, 1999). Therefore, it is of great importance to measure the level of emotional climate that occurs in the educational institutions where the future of the society is shaped and take actions to increase the level of positive climate. In the literature, although there exist various scales that measure emotional climate (Liu, Härtel \& Sun, 2014; Yurtsever \& De Rivera, 2010), none is suitable to measure emotional climate in schools. This study aims to develop and validate the School's Emotional Climate scale.

\section{METHOD}

\section{Participants}

In order to select the participants, stratified sampling technique was employed. The participants consisted of 683 teachers working in primary and secondary schools in five different education districts with different socio-economic and cultural characteristics in a city located in the eastern part of Turkey during 2018-2019 school year. Through stratified sampling, the sample consisted of participants that is reflective of the larger population and the results have a higher statistical accuracy (Güneş \& Arıkan, 1988).

In the literature, there exist various criteria for sample selection in regard to scale development studies. While Maccallum and colleagues (2001) mentioned the ratio 4:1 based on the number of items in the selected questionnaire, other researchers reported ratio of $5: 1$ or 10:1 (Tavşanc1l, 2002; Büyüköztürk, 2018; Kurnaz \& Yiğit, 2010). Also, Guilford (1954) stated that there should be at least 200 participants in the scale development studies. Moreover, Comrey and Lee (2013) and De Vellis (2014) rated the number of samples and considered 200 participants as moderate, 300 as good, and 1000 as excellent. Besides all these, Çokluk, Şekercioğlu and Büyüköztürk (2018) stated that even when developing a 10-item scale, at least 300 participants need to be reached. In addition, for the Exploratory Factor Analysis (EFA) and Confirmatory Factor Analysis (CFA) to validate a scale, it is critical to obtain data from two different sample groups (Fabrigar, Wegener, MacCallum and Strahan, 1999). Therefore, in the current study two sample groups (336 participants for EFA and 347 participants for CFA) were recruited.

There were 316 male and 367 female participants in the study. While there were 351 elementary school teachers, the rest was middle school teachers from various branches. With regard to teaching experience 15 teachers $(2 \%)$ had less than one-year experience, 60 (9\%) had 1-5 years of experience, $82(12 \%)$ had 6-10 years of experience, $129(19 \%)$ had 11-15 years of experience, and $397(58 \%)$ had more than 16 years of experience.

\section{Data Collection Tool}

In order to develop the School's Emotional Climate scale (SEC-S), an extensive literature review was conducted and similar studies were identified (Yurtsever and De Rivera, 2010; Liu, Härtel and Sun, 2014). Based on these studies and expert views, a pool consisting of 39 items related to employees' emotional coexistence, emotional exhaustion and emotional interaction between the school administration and the teachers were formed. In terms of content validity, the items were reviewed by six experts from the Department of Educational Management, two experts from the Department of Education Programs, one expert from the Department of Computer Science and Instructional Technologies, and one expert from the Department of Turkish Education. In regard to expert views', three items were re-constructed and seven items were dropped out from the item pool, which left 32 items in total. The final draft of the SEC-S was reviewed by an expert from the Department of Turkish Education in terms of its language and grammar. The items in the scale were organized according to five-point Likert type scale with potential responses of strongly disagree, disagree, neutral, agree, and strongly agree.

\section{Procedure}

After constructing the scale, the required permissions from the Ministry of Education was obtained. The data collection process took about three months during the spring semester of 2018-2019 school year. Each school was visited by the researchers and the study was introduced to the participants individually during weekday time. The printed version of the scale was delivered to the participants. It took approximately 10 minutes for participants to fill out the scale. After the data collection process, all data was transformed into an electronic format for analysis.

\section{Data Analysis}

To ensure the construct validity of the scale, first, EFA was performed, and then, this structure was tested through CFA. In EFA, similar variables are collected under the same factor by using the relationship among the items and different factors are formed in itself. In CFA, this structure is statistically tested and verified (Büyüköztürk, 2018; Tabachnick \& Fidell, 2007). In order to test the reliability of the scale, the internal consistency coefficient of Cronbach Alpha was used. For EFA and CFA, 336 and 347 cases were used, respectively. Then, in order to calculate Cronbach Alpha value, all cases were combined together $(n=683)$. Kaiser-Meyer-Olkin (KMO) coefficient and Bartlett Sphericity Test were used to test the suitability of the data for factor analysis. A computer-based statistics program was used for all data analysis.

\section{FINDINGS}

\section{Results of Exploratory Factor Analysis}

For the construct validity of the School's Emotional Climate Scale, first, exploratory factor analysis was conducted. The negatively worded items 14, 15, 16, 21, 23, 27, 30, and 31 were reverse coded. Then, KMO and Bartlett tests were performed to test the suitability of the data for factor analysis. In order for a scale to be ready for EFA, KMO value needs to be higher than .60 and Bartlett Sphericity test result 
needs to be significant $(\mathrm{p}<$.01) (Büyüköztürk, 2018). The results revealed that the data was suitable for factor analysis (KMO: 0.902; Bartlett's Test of Sphericity: 3535.046, $\mathrm{p}=0.000$ ). Varimax (25) rotation technique was used for the extraction of factors. In EFA, each factor loading needs to be higher than .30 in order for an item to remain in the scale (Büyüköztürk, 2002; Field, 2009; Pallant, 2013) and the difference between item loadings for cross loaded items is not less than 1 (Costello \& Osborne, 2005).

During the first stage of the factor analysis, items 5, 13, 18 , and 19 were removed from the scale since their loadings were less than .30 , and then, the analyses was repeated. In the second round, items 22, 23, and 27 were cross loaded and the difference between loading values were less than .1 and loading values of item 26, 31, and 32 were less than .30. Therefore, these six items were dropped out from the analysis. In the third round, items 6, 24, and 25 were removed from the scale because their loadings were less than .30 , which left 19 items with three factors in the scale. Based on the factors, the items were re-numbered. Item loadings and factors are given in Table 1 and the scree plot is shown in Figure 1.

Generally, the factor loading values in the literature were expected to be higher than .20 (Şencan, 2005), .40 (Costello \& Osborne, 2005; Tabachnick \& Fidell, 2007), .45 (Büyüköztürk, 2018) or .50 (Thompson, 2004). In this study, the lowest item factor loading was .48 , which implies that all item loadings were met the criterion. The obtained factors were entitled as Emotional Association, Empathy, and Emotional Fatigue. The emotional association factor consisted of 10 items with factor loadings ranging between .480 and .740 and explains $40.175 \%$ of the total variance; the empathy factor consisted of four items with factor loadings ranging between .665 and .878 and explains $11.882 \%$ of the total variance; and the emotional fatigue factor consisted of five items with factor loadings ranging between .515 and .865 and explains $7.263 \%$ of the total variance. Altogether, three factors explain $59.319 \%$ of the total variance.

After obtaining EFA results, a correlation matrix was created in order to examine the correlations between the factors of the scale (Table 2). Although the results demonstrated positive and significant correlations between the factors, the highest correlation was observed between the emotional association and empathy factors.

\section{Results of Confirmatory Factor Analysis}

In order to test the accuracy of the EFA results, CFA was conducted. The scale was administered to 347 participants who did not participate in the first stage of the study in which data was collected for EFA. The chi-square to degrees of freedom ratio $(284.906 / 146=1.951)$ was found after the generated model. In general, values below 2 are considered to indicate a good fit. Also, other values obtained from the analysis were proof of good agreement (CFI $=.960$, NFI $=$ $.921, \mathrm{GFI}=.917, \mathrm{SRMS}=.043$, RMSEA $=.052$ ). The results and the reference values are given in Table 3

Sources: (Çokluk, Şekercioğlu \& Büyüköztürk, 2018; Sümer, 2000; Tabachnick \& Fidell, 2007; SchermellehEngel, Moosbrugger \& Müller, 2003; Bentler, 1980; Marsh,
Hau, Artelt, Baumart \& Peschar, 2006; Browne \& Cudeck, 1993; Byrne 2001)

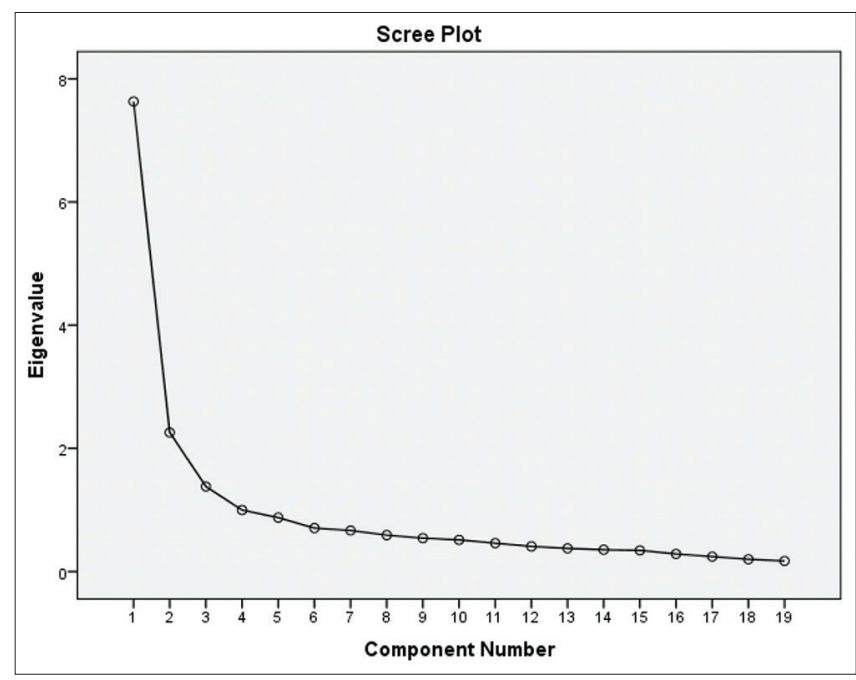

Figure 1. SEC-S Eigenvalue line graph

Table 1. SEC-S Item Loadings and Factors

\begin{tabular}{lccc}
\hline Item number & Factor 1 & Factor 2 & Factor 3 \\
\hline 6 & .740 & & \\
5 & .728 & & \\
10 & .722 & & \\
17 & .718 & & \\
7 & .713 & & \\
15 & .704 & & \\
8 & .657 & & \\
18 & .647 & & \\
9 & .634 & & \\
14 & .480 & & \\
2 & & .878 & \\
3 & & .802 & \\
1 & & .780 & .865 \\
4 & & .665 & .802 \\
12 & & & .614 \\
13 & & & \\
11 & & & \\
16 & & & \\
Eigenvalue & & & \\
Total & & & \\
\hline
\end{tabular}

Table 2. Correlation matrix of the three factors

\begin{tabular}{lccccc}
\hline Factors & $\mathbf{1}$ & $\mathbf{2}$ & $\mathbf{3}$ & Mean & Std. Deviation \\
\hline 1 - Emotional & 1 & & & 3.7055 & .63299 \\
Association & & & & & \\
2 - Empathy & $.649^{* *}$ & 1 & & 3.5251 & .76134 \\
3 - Emotional & $.411^{* *}$ & $.305^{* *}$ & 1 & 3.6349 & .77344 \\
Fatigue & & & & & \\
\hline
\end{tabular}




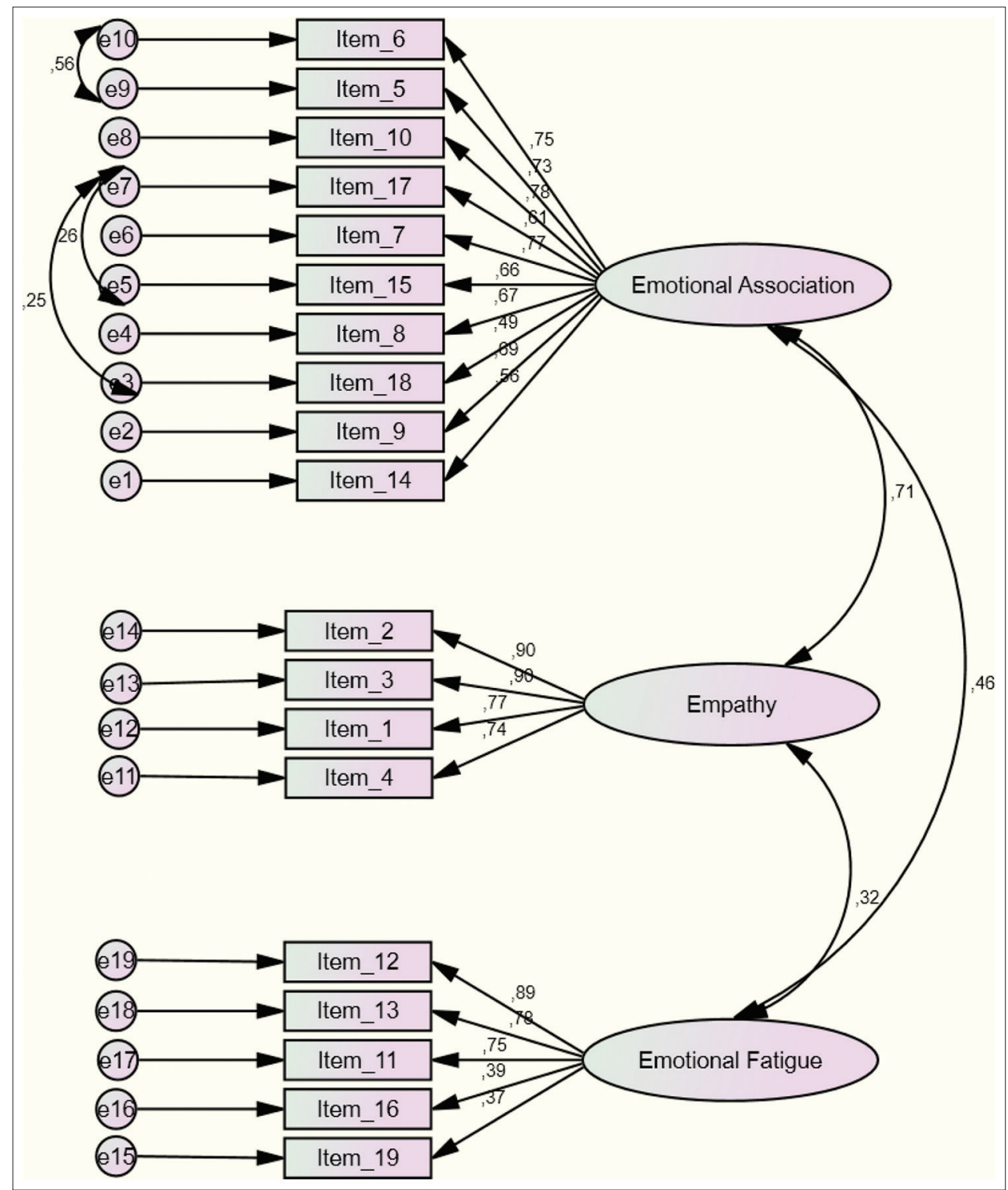

Figure 2. The final model and values

Table 3. The results of testing the overall model fit and recommended values

\begin{tabular}{lcccc}
\hline Notation & Perfect fit values & Recommended value & Calculated value & Result \\
\hline $\mathrm{X}^{2} / \mathrm{sd}$ & $0 \leq \mathrm{X}^{2} / \mathrm{sd} \leq 2$ & $2 \leq \mathrm{X}^{2} / \mathrm{sd} \leq 3$ & 1.951 & Perfect fit \\
$\mathrm{GFI}$ & $.95 \leq \mathrm{GFI} \leq 1.00$ & $.90 \leq \mathrm{GFI} \leq 95$ & .917 & Acceptable fit \\
$\mathrm{CFI}$ & $.97 \leq \mathrm{CFI} \leq 1.00$ & $.95 \leq \mathrm{CFI} \leq .97$ & .960 & Acceptable fit \\
$\mathrm{NFI}$ & $.95 \leq \mathrm{NFI} \leq 1.00$ & $.90 \leq \mathrm{NFI} \leq .95$ & .921 & Acceptable fit \\
RMSEA & $.00 \leq \mathrm{RMSEA} \leq .05$ & $.05 \leq \mathrm{RMSEA} \leq .08$ & .052 & Acceptable fit \\
\hline
\end{tabular}

According to the CFA results, the factor loadings of the items under the emotional association dimension were .751 , $.727, .778, .613, .774, .662, .674, .491, .688$ and .555 ; the factor loadings of the items under the empathy dimension were.904, .904, .768 and .739; and the factor loadings of the items under the emotional fatigue dimension were .892, .785, $.752, .386$ and .372 respectively. Three covariance paths were added between items 7 and 8, items 20 and 28, and items 28 and 29. The final model is presented in Figure 2.

\section{Reliability}

Cronbach alpha reliability coefficient was calculated in order to ensure the reliability of SEC-S. According to the literature, scales with reliability coefficient values higher than .70 are considered as reliable (Domino \& Domino, 2006; Fraenkel, Wallen \& Hyun, 2011). The reliability coefficient values for the emotional association, empathy, and emotional fatigue were calculated as $.896, .884$, and .782 , respectively. In 
Table 4. Cronbach alpha values of SEC-S

\begin{tabular}{lc}
\hline Factors & Cronbach alfa katsayıs \\
\hline Emotional association & .896 \\
Empathy & .884 \\
Emotional fatigue & .782 \\
Total & .905 \\
\hline
\end{tabular}

addition, the total item reliability coefficient of the scale was found to be .905 . The results revealed that the scale itself and its factors were reliable. The results are presented in Table 4.

\section{CONCLUSION}

The presence of a person brings with it emotions. In the literature, there exist many scales to measure, specifically in work life, the emotional climate created by the emotional interactions among people. However, in the literature, there is no scale to measure the emotional climate in schools which are the most important centers of education. This study aims to fill the gap in the literature. In this respect, this particular study was conducted to develop the School's Emotional Climate Scale. The sample of the study consisted of 683 teachers serving in primary and secondary schools in a city located in the eastern part of Turkey during 20182019 school year. An item pool with 39 items was created based on the literature review and expert opinions. After the expert opinions, the final version of the scale with 32 items was constructed. It was a five-point Likert type scale ranging from strongly disagree to strongly agree. First, required permissions were obtained, and then, the scale was administered to 336 teachers.

Exploratory Factor Analysis was performed to provide evidence for structural validity over the data. As a result of the analysis, 13 items were excluded from the scale and the School's Emotional Climate Scale with 19 items and three factors was constructed. The factor loadings varied between .480 and .878. While Factor 1 explains $40.175 \%$ of total variance, Factor 2 and 3 explain $11.882 \%$ and $7.263 \%$ of total variance, respectively. All factors of the scale explained $59,319 \%$ of the total variance. The factors were entitled as Emotional Association, Empathy, and Emotional Fatigue.

In order to test the EFA results, the final scale was administrated to 347 teachers who did not participate the first part of the study. CFA was employed and the chi-square to degrees of freedom ratio was calculated as 1.951 . According to the ratio and the other values $(\mathrm{CFI}=.960, \mathrm{NFI}=.921, \mathrm{GFI}=.917$, $\mathrm{SRMS}=.043$, RMSEA=.052), the SEC-S was found reliable (Hair, Anderson, Tatham \& Black, 1998; Kline, 2015; Raykov \& Marcoulides, 2006; Baumgartner \& Homburg, 1996). In the last stage of the study, both EFA and CFA data were combined to calculate Cronbach alpha reliability coefficient value for the factors and the scale itself. It was found that the reliability coefficient value was in acceptable range between .782 and .905 , which is considered as an evidence for the scale to be reliable.

As a result, it is concluded that the School's Emotional Climate Scale is a valid and reliable scale. The scale can be used in the studies in order to determine the level of emotional climate caused by the interactions among school staff. Future studies may use this scale to determine the association among schools' emotional climate and other variables including organizational commitment, organizational cynicism, job satisfaction, organizational support, and so on.

Although this study has good psychometric properties in terms of scale development, it has some limitations. First, the participants of the study consisted of 683 teachers serving in elementary and middle schools in a city located in eastern part of Turkey, which led to sample-specific results. Therefore, this may limit the generalization of the results for all population. A future replication of the study is suggested for future research with other rural and urban populations. Second, although two different samples were studied for both EFA and CFA, more research is needed for validation with larger as well as cross-cultural samples. The last limitation is that this study included only SEC-S. Future research must include other scales related to, for instance, organizational commitment, organizational cynicism, job satisfaction, and organizational support in order to determine whether there is any association between emotional climate of schools and other variables.

\section{REFERENCES}

Akçay, C. \& Çoruk, A. (2012). Çalışma yaşamında duygular ve yönetimi: Kavramsal bir inceleme. Eğitimde Politika Analizi, 1(1), 3-25.

Akın, M. (2004). Isşletmelerde duygusal zekânın üst kademe yönetimciler ile astlar arasındaki çatışmalar üzerindeki etkileri (Kayseri'deki büyük ölçekli işletmelerde bir uygulama) (Unpublished Doctoral Thesis). Anadolu Üniversitesi, Eskişehir.

Baumgartner, H., \& Homburg, C. (1996). Applications of structural equation modeling in marketing and consumer research: A review. International Journal of Research in Marketing, 13(2), 139-161.

Bellocchi, A., Ritchie, S. M., Tobin, K., Sandhu, M., \& Sandhu, S. (2013). Exploring emotional climate in pre service science teacher education. Cultural Studies of Science Education, 8(3), 529-552.

Bentler, P.M. (1980). Multivariate analysis with latent variables: Causal modeling. Annual Review of Psychology, 31, 419-456.

Browne, M.W., \& Cudeck, R. (1993). Alternative ways of assessing model fit. In: Bollen, K.A., \& Long, J.S. (Eds.), Testing structural equation models (pp. 136-162). Beverly Hills, CA: Sage

Büyüköztürk, Ş. (2002). Faktör analizi: Temel kavramlar ve ölçek geliştirmede kullanımı. Kuram ve Uygulamada Ĕ̈itim Yönetimi, 32(32), 470-483.

Büyüköztürk, Ş. (2018). Sosyal bilimler için veri analizi el kitabl. Ankara: Pegem Akademi Yayınları.

Byrne, B.M. (2001). Structural equation modeling with AMOS, EQS, and LISREL: Comparative approaches to testing for the factorial validity of a measuring instrument. International Journal of Testing, 1(1), 55-86.

Comrey, A. L., \& Lee, H. B. (2013). A First course in factor analysis. (2 ${ }^{\text {th }}$ Edition), New Jersey: Lawrence Erlbaum Associates. 
Costello, A. B., \& Osborne, J. W. (2005). Best practices in exploratory factor analysis: Four recommendations for getting the most from your analysis. Practical Assessment, Research \& Evaluation, 10(7), 1-9.

Çokluk, Ö., Şekercioğlu, G., \& Büyüköztürk, Ş. (2018). Sosyal bilimler için çok değişkenli istatistik: SPSS ve LISREL uygulamalarl. Ankara, Pegem Yayıncılık.

De Rivera, J., \& Páez, D. (2007). Emotional climate, human security, and cultures of peace. Journal of Social Issues, 63(2), 233-253.

De Vellis, R. F. (2014). Ölçek geliştirme: Kuram ve uygulamalar (Çev. Ed. T. Totan). Ankara: Nobel Akademik.

Edmondson, A. (1999), Psychological safety and learning behavior in work teams. Administrative Science Quarterly, 44(2), 35-383.

Erkuş, A., \& Günlü, E. (2008). Duygusal zekânın dönüşümcü liderlik üzerine etkileri. Dokuz Eylül Üniversitesi İşletme Fakültesi Dergisi, 9 (2), 187-209.

Fabrigar, L. R., Wegener, D. T., MacCallum, R. C., \& Strahan, E. J. (1999). Evaluating the use of exploratory factor analysis in psychological research. Psychological Methods, 4(3), 272-299.

Field, A. P. (2009). Discovering statistics using SPSS. London, England: SAGE.

Fineman, S. (1993). Organizations as emotional arenas. London, England: Sage Publications.

Fraenkel, J. R., Wallend, N. E., \& Hyun, H. H. (2011). How to design and evaluate research in education. New York: McGrawHill.

Günes, T., \& Arikan, R. (1988). Tarım Ekonomisi İstatistiği. Ankara Üniversitesi Ziraat Fakültesi, Yayin, (1049).

Guilford, J. P. (1954). Psychometric methods, Newyork: Mc Graw Hill.

Hair, J. F. Jr., Anderson, R. E., Tatham, R. L., \& Black, W. C. (1998). Multivariate data analysis, (5 $5^{\text {th }}$ Edition). Upper Saddle River, NJ: Prentice Hall.

Hargreaves, A. (2000). Mixed emotions: teacher's perceptions of the interactions with student. Teaching and Teacher education, 16, 811-826.

Jöreskog, K., \& Sörbom, D. (1993). LISREL 8: Structural Equation Modeling with the SIMPLIS Command Language. Lincolnwood, USA: Scientific Software International, Inc

Kahn, W. A. (1993), Caring for the caregivers: Patterns of organizational care-giving, Administrative Science Quarterly, 38, 539-63.

Kervancı, F. (2008). Büro çalışanlarının duygu yönetimi yeterlilik düzeylerinin geliştirilmesinde duygu yönetimi eğitimi programının etkisi (Unpublished Master Thesis). Gazi Üniversitesi, Eğitim Bilimleri Enstitüsü, Büro Yönetimi Eğitimi Anabilim Dalı, Ankara, Türkiye.

Kirel, Ç. (2007). Örgütlerde mobbing yönetiminde destekleyici ve risk azaltıcı öneriler, Anadolu Üniversitesi Sosyal Bilimler Dergisi, 7(2), 317-334.

Kline, R. B. (2015). Principle sand practice of structural equation modeling ( $4^{\text {th }}$ ed.). New York London: The Guilford Press.

Yiğit, N., \& Kurnaz, M. A. (2010). Fizik tutum ölçeği: Geliştirilmesi, geçerliliği ve güvenilirliği. Necatibey
Eğitim Fakültesi Elektronik Fen ve Matematik Eğitimi Dergisi, 4(1), 29-49.

Liu, X. Y., Härtel, C. E., \& Sun, J. J. M. (2014). The work group emotional climate scale: Theoretical development, empirical validation, and relationship with workgroup effectiveness. Group \& Organization Management, 39(6), 626-663.

MacCallum, R. C., Widaman, K. F., Preacher, K. J., \& Hong, S. (2001). Sample size in factor analysis: the role of model error. Multivariate Behavioral Research, 36(4), 611-637.

Marsh, H.W., Hau, K.T., Artelt, C., Baumert, J., \& Peschar, J.L. (2006). OECD's brief self-report measure of educational psychology's most useful affective constructs: Cross-cultural, psychometric comparisons across 25 countries. International Journal of Testing, 6(4), 311-360.

Pallant, J. (2013). SPSS survival manual: A step by step guide to data analysis using SPSS for Windows (5th ed.). Berkshire: Open University Press.

Raykov, T., \& Marcoulides, G. A. (2006). On multilevel model reliability estimation from the perspective of structural equation modeling. Structural Equation Modeling, 13, 130-141.

Ruiz, J. I. (2007). Emotional climate in organizations: Applications in Latin American prisons. Journal of Social Issues, 63 (2), 289-306.

Schermelleh-Engel, K., Moosbrugger, H., \& Müller, H. (2003). Evaluating the fit of structural equation models: Tests of significance and descriptive goodness-of-fit measures. Methods of Psychological Research Online, $8(2), 23-74$.

Seçer, H. Ş. (2005). Çalışma yaşamında duygular ve duygusal emek: Sosyoloji, psikoloji ve örgüt teorisi açısından bir değerlendirme. Sosyal Siyaset Konferanslart Dergisi, (50), 813-834.

Schutz, P. A., Aultman, L. P., \& Williams-Johnson, M. R. (2009). Educational psychology perspectives on teachers' emotions. In P. A. Schutz\& M. Zembylas (Eds.), Advances in teacher emotion research. The impact on teachers' lives (pp. 195-212). Dordrecht: Springer.

Sümer, N. (2000). Yapısal eşitlik modelleri: temel kavramlar ve örnek uygulamalar. Türk Psikoloji Yazıları, 3(6), 74-79.

Şencan, H. (2005). Sosyal ve davranışsal ölçümlerde güvenirlik ve geçerlilik. Ankara: Seçkin Yayıncılık.

Tabachnick, B. G., \& Fidell, L. S. (2007). Using multivariate statistics ( $5^{\text {th }}$ ed.). Boston: Pearson Education.

Tavşancıl, E. (2002). Tutumların ölçülmesi ve SPSS ile veri analizi. Nobel Yayıncılık, Ankara.

Thapa, A., Cohen, J., Guffey, S., \& Higgins-D’Alessandro, A. (2013). A review of school climate research. Review of Educational Research, 83(3), 357-385.

Thompson, B. (2004). Exploratory and confirmatory factor analysis: Understanding concepts and applications. Washington DC: American Psychological Association.

Tobin, K., Ritchie, S. M., Oakley, J., Mergard, V., \& Hudson, P. (2013). Relationships between EC and the fluency of classroom interactions. Learning Environment Research,.doi:10.1007/s10984-013-9125-y. 
Turner, J. H. (2007). Human emotions: A sociological theory. London: Routledge.

Yurtsever, G., \& De Rivera, J. (2010). Measuring the emotional climate of an organization. Perceptual and motor skills, 110(2), 501-516.
Zembylas, M. (2005). Creating a supportive emotional tone for learning in the classroom. In M. Zembylas (Ed.), Teaching with emotion: a postmodern enactment (Vol. 4, pp. 65-94). Conneticut, USA: Information Age Publishing. 